\title{
H2AC1 wt Allele
}

National Cancer Institute

\section{Source}

National Cancer Institute. H2AC1 wt Allele. NCI Thesaurus. Code C162885.

Human H2AC1 wild-type allele is located in the vicinity of $6 \mathrm{p} 22.2$ and is approximately 1 $\mathrm{kb}$ in length. This allele, which encodes histone H2A type 1-A protein, plays a role in DNA compaction. 